\title{
Effect of Tubifex and Carrot Meal Combination on Color Quality of Botia Chromobotia macracanthus
}

\author{
Yuli Andriani ${ }^{1, *}$, Rosidah $^{1}$, Iskandar $^{1}$, Agus $_{\text {Priyadi }}{ }^{2}$, and Satria N. Firdaus ${ }^{3}$ \\ ${ }^{1}$ Faculty of Fishery and Marine Science, University Padjadjaran, 45363 West Java, Indonesia \\ ${ }^{2}$ Center for Research and Development of Ornamental Fish Center, 16436 West Java, Indonesia \\ ${ }^{3}$ Alumny Faculty of Fishery and Marine Science, University Padjadjaran, 45363 West Java, Indonesia
}

\begin{abstract}
Colour is the most important indicators of quality in ornamental fish, making the exploration to find new sources of pigments in ornamental fish is growing. This study aimed to determine the optimum dose of tubifex and carrot meal combination to enhance the quality of color in Botia Chromobotia macracanthus. This study was designed using Completely Randomized Design with six treatments in triplicates: a) commercial feed (control), b) $70 \%$ Tubifex $+3 \%$ carrot meal $+27 \%$ commercial feed, c) $60 \%$ Tubifex $+4 \%$ carrot meal $+36 \%$ commercial feed, d) $50 \%$ Tubifex $+5 \%$ carrot meal $+45 \%$ commercial feed, e) $40 \%$ Tubifex $+6 \%$ carrot meal + $54 \%$ commercial feed, and f) $30 \%$ Tubifex $+7 \%$ carrot meal $+63 \%$ commercial feed. Parameters observed were color change level, which was tested using the Kruskal-Wallis method; survival rate (SR) tested using analysis of variance through the F test; and water quality. Results showed that the best color enhancement seen in treatment with 50\% Tubifex $+5 \%$ carrot meal $+45 \%$ commercial feed combination with an average body color of 5.04 in Toca Colour Finder code 0605. The caudal fin color was enhanced with an average score of 3.93 in code 0805 .
\end{abstract}

\section{Introduction}

Botia fish (Chromobotia macracantuhs Bleeker) is a native ornamental freshwater fish of Indonesia that live in Sumatra and Kalimantan water[1]. Many people like botia fish because it has an attractive color with reddish dark yellow as the base color with vertical dark greyblack stripes in three places [2]. Color is one of the important factors to be considered by fish farmers who work with Botia fish as ornamental fish [3]. Apart from genetic factors, the color of ornamental fish can be improved through the selection of feed that contains appropriate nutrients and vitamins for ornamental fish. Based on its function, the fish feed can be divided into 2 groups, i.e. staple feed with high nutrition contents that are usually found in natural food and additional food that relies on manufactured feed added with vitamins to meet the fish needs [4].

Staple feed is used to increase fish growth rate and survival rate. According to [2], the natural food that increase the growth rate of botia fish seeds is Tubifex. Tubifex natural feed contains $57 \%$ protein, $13.3 \%$ fat, $2.04 \%$ crude fiber, $3.6 \%$ ash, and $87.7 \%$ moisture

\footnotetext{
*Corresponding author: yuli.andriani@unpad.ac.id
} 
content [5]. In addition to its ability to increase fish growth rate and survival, this feed also helps to improve the quality of color in ornamental fish, due to its high-fat content that functions as an organic solvent of carotenoid as the main source for color pigment formation in ornamental fish [6]. The addition of carotenoids into feed as supplementary food is performed to meet the fish needs. Carotenoids can be found in plants and animal products, such as fruits, vegetables, eggs, lobsters, and some types of fish [7]. Carrot is one of the vegetables with a quite high $\beta$-carotene content that can be used to improve the quality of goldfish (Carassius auratus) color [8]. Tubifex is a natural fat supply that can be used as an alternative considering the high price of natural feed. Carrot meals with high $\beta$-carotene content will add the value of fish feed without significantly increasing the price. Therefore, a study to understand the effect of Tubifex and carrot meal combinations addition to feed on the quality of botia fish color is needed.

This study aimed to determine the optimum dose of tubifex and carrot meal combinations to enhance the quality of color in Botia fish.

\section{Materials and Methods}

\subsection{Materials and tools}

This study used ninety botia fish seeds (Chromobotia macracanthus Bleeker) with 4.8-6 cm of total length which were measured using a millimeter block with an accuracy of $1 \mathrm{~mm}$. The weight range of the seeds was $1.8-2.5 \mathrm{~g}$ which were weighed using an analytical scale with an accuracy of $0.01 \mathrm{gr}$. Eighteen $40 \mathrm{~cm} \times 30 \mathrm{~cm} \times 30 \mathrm{~cm}$ aquariums were used in this with a density of five fish per aquarium. The density in this study was low because it was adjusted to botia fish habits. The test feed consisted of various combinations of Tubifex natural feed and carrot meal mixed with Feengli B 0 commercial feed and 2\%/100 g CMC (Carboxymethyl Cellulose) as the binder. The feed was pelleted using a pelletizer. The quality of fish color quality was measured using the Toca Color Finder tool with a scale of 1-6 for the body color and 1-5 for caudal fin color.

\subsection{Method}

Completely Randomized Design (CRD) with 6 treatments in triplicates was used. Treatments in this study were:

Treatment $\mathrm{A}$ Control $=$ The feed without adding carrot meal and Tubifex.

Treatment $\mathrm{B}=70 \%$ Tubifex $+3 \%$ carrot meal in $27 \%$ commercial feed.

Treatment $\mathrm{C}=60 \%$ Tubifex $+4 \%$ carrot meal in $36 \%$ commercial feed.

Treatment $\mathrm{D}=50 \%$ Tubifex $+5 \%$ carrot meal in $45 \%$ commercial feed.

Treatment $\mathrm{E}=40 \%$ Tubifex $+6 \%$ carrot meal in 54\% commercial feed.

Treatment $\mathrm{F}=30 \%$ Tubifex $+7 \%$ carrot meal in $63 \%$ commercial feed.

\subsection{Procedure}

This study was performed in several stages including acclimatization of botia fish by feeding commercial feed in ad libitum for 21 days; self-production of carrot meal from fresh carrots that were processed into powder; making test feed based on the combination for each treatment; soaking Tubifex worms in $0.1 \mathrm{ml} / \mathrm{L}$ Acriflavine HCL BPL solution to prevent disease or fungi transmission to test fish; pouring water from the former aquarium that had gone through the immersion process using 1\% PK (Potassium Permanganate) solution for 24 
hours; installing aeration in each aquarium media; transferring test fish into the aquarium with a density of 5 fish per aquarium; and measuring sample of fish to measure the quality of colors using Toca Color Finder at the beginning of the study with the help of at least 3 people who were not color blind. The survival rate and water quality were also measured at the beginning of the study as baseline data. Feeding was performed at different times with test pellet feed provided first until it was all consumed, followed by feeding with Tubifex natural feed. The feeding dose was $10 \%$ of the total weight of fish biomass per aquarium, twice a day at 08:00 and 16:00 WIB for 40 days. Fish sampling for measurement was conducted every 10 days. The water quality was maintained by siphoning every morning before the test fish received pellet feed.

\subsection{Observation Parameters}

\subsubsection{Color Change Level}

Observation of the color change level was performed every 10 days using the Toca Color Finder (TCF) tool, starting from day 0 to collect baseline data on the pre-treatment color. The parameters observed were a color enhancement on the body and caudal fin of botia fish (Tables 1 and 2).

Table 1. Colour Code of Toca Colour Finder for Fish Body Color.

\begin{tabular}{|c|c|c|c|c|c|c|}
\hline \multicolumn{7}{|c|}{ Number Scoring } \\
\hline & 1 & 2 & 3 & 4 & 5 & 6 \\
\hline \multicolumn{7}{|c|}{ Colour Toca Colour Finder Body } \\
\hline & 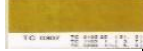 & 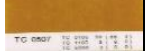 & 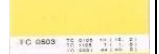 & 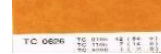 & ro one $y=19$ & roms 배 \\
\hline \multirow[t]{2}{*}{ Code TCF } & 0307 & 0507 & 0503 & 0626 & 0624 & 0704 \\
\hline & 1000000 & 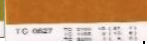 & 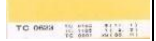 & 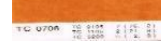 & 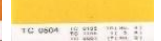 & 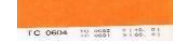 \\
\hline \multirow[t]{2}{*}{ Code TCF } & 0308 & 0627 & 0623 & 0706 & 0504 & 0604 \\
\hline & 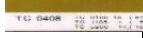 & то osose is: & 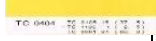 & 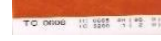 & roomen in & 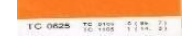 \\
\hline \multirow[t]{2}{*}{ Code TCF } & 0408 & 0506 & 0404 & 0606 & 0405 & 0625 \\
\hline & To 0000 by & 60000 & 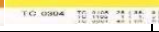 & 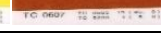 & 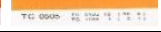 & \\
\hline \multirow[t]{2}{*}{ Code TCF } & 0508 & 0406 & 0304 & 0607 & 0505 & 0605 \\
\hline & 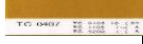 & recoso $: 13=4$ & 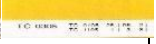 & मस्या हा & 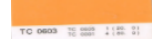 & Ta \\
\hline Code TCF & 0407 & 0306 & 0305 & 0616 & 0603 & 0614 \\
\hline
\end{tabular}

\subsubsection{Survival Rate}

The survival rate was also observed every day by counting and recording the number of survive fish. The fish survival rate was calculated using the following formula [9]:

$$
\text { Survival Rate }(S R)=\frac{\text { Number of Fish at the End of Experiment }}{\text { Number of Fish at the Beginning of Experiment }} \times 100 \%
$$




\subsubsection{Water Quality}

Water quality parameters need to be observed to ensure a good survival rate of the fish. It also affects the color quality of ornamental fish. Parameters measured in this study were temperature, $\mathrm{pH}$, dissolved oxygen (DO), and ammonia level. Water sampling was conducted at the beginning and the end of the experiment.

Table 2. Colour Code of Toca Colour Finder for caudal fin color.

\begin{tabular}{|c|c|c|c|c|c|}
\hline \multicolumn{6}{|c|}{ Number Scoring } \\
\hline & 1 & 2 & 3 & 4 & 5 \\
\hline \multicolumn{6}{|c|}{ Colour Toca Colour Finder caudal fin } \\
\hline & 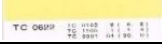 & 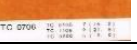 & 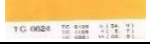 & 100000 & Te oxos a \\
\hline \multirow[t]{2}{*}{ Code TCF } & 0622 & 0706 & 0624 & 0806 & 0705 \\
\hline & 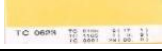 & 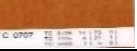 & 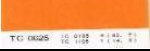 & & 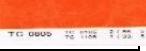 \\
\hline \multirow[t]{2}{*}{ Code TCF } & 0623 & 0707 & 0625 & 0807 & 0805 \\
\hline & 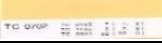 & $\mathrm{romos}$ 글 & 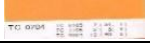 & 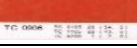 & \\
\hline \multirow[t]{2}{*}{ Code TCF } & 0702 & 0808 & 0704 & 0906 & 0815 \\
\hline & 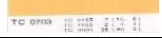 & & 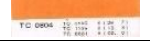 & & \\
\hline Code TCF & 0703 & 0709 & 0804 & 0907 & 0905 \\
\hline & 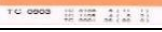 & & & & \\
\hline Code TCF & 0903 & 0908 & & & \\
\hline
\end{tabular}

\subsubsection{Data Analysis}

Data on the color enhancement of botia fish were analyzed using Kruskal-Wallis one-way test. When differences between treatments were found, the $Z$ test with a $95 \%$ confidence level was conducted. Survival rate data were analyzed by using analysis of variance with the F test with a confidence level of $95 \%$. When differences between treatments were found, Duncan test with a confidence level of $95 \%$ was performed. Water quality data were analyzed using the descriptive method.

\section{Results and Discussion}

\subsection{Color Change Level}

Results of 40-day observation using the Toca Color Finder tool showed the presence of color enhancement on the body and caudal fin of the botia fish. In treatment A (control), the average values of color enhancement were 3.4 for the body color and 2.66 for caudal fin color. In treatment B $(70 \% \mathrm{Tbx}+3 \% \mathrm{Cm})$, the average values for body and caudal fin color enhancement were 4.37 and 3.55, respectively. In treatment $C(60 \% \mathrm{Tbx}+4 \% \mathrm{Cm})$, the average color enhancement values were 4.06 for body and 3.37 for caudal fin. The average color values in treatment $\mathrm{D}(50 \% \mathrm{Tbx}+5 \% \mathrm{Cm})$ gave an average value of 5.04 for body and 3.39 for the caudal fin. In treatment $\mathrm{E}(40 \% \mathrm{Tbx}+6 \% \mathrm{Cm})$ color enhancement average values for body and caudal fin were 4.62 and 3.37 , respectively. In treatment $\mathrm{F}(30 \% \mathrm{Tbx}+7 \%$ $\mathrm{Cm}$ ), the average color value was 4.44 for body and 3.26 for caudal fin. The addition of color enhancer sources in the feed will encourage increased color pigment in the fish body, or at least will be able to maintain the color pigment in the body during maintenance [14]. These 
average values were gained from scoring using Toca Colour Finder. Increases were seen in each treatment (Figure 1).

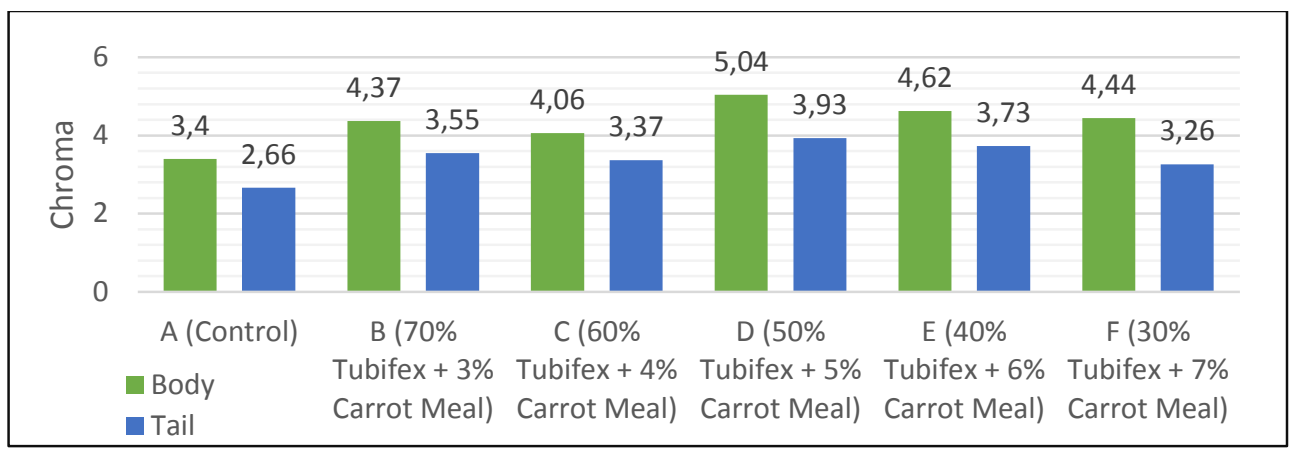

Fig. 1. Average Value of Botia Fish Color after being Fed with Diet Containing Different Level

Tubifex and Carrot Meal

An assumption was made that a combination of Tubifex and carrot meal diet resulted in a color quality enhancement in botia fish due to, among others, the effect of Tubifex that played an active role as a supplier of high nutrients, especially fat. According to [10], the use of Tubifex natural feed and commercial feed combination causes a significant difference in fat retention in eels. Fat plays a role as a vitamin solvent for vitamin A, D, E, and $\mathrm{K}$ as well as in converting carotene into vitamin A [11]. Carotenoids have various forms of compounds, one of which is carotene. Carotene binding to proteins is called carotenoprotein. These compounds when experiencing a process of heating will split into protein and carotene which can produce a red color [12]. The process of $\beta$-carotene source decomposition in carrot meal includes a conversion by a $B$-carotene enzyme that yields 2 retinol molecules (vitamin A) and degradation by fat that is contained the feed. Retinol then experiences reesterification with long-chain fatty acids and is incorporated into the lymphatic chylomicron to eventually enter the bloodstream [13]. Retinol is transported to the liver and binds with palmitic acid, which is then stored in the form of retinyl-palmitate. Retinol palmitate is then bound by the retinolbinding protein (PPR) which is synthesized in the liver and transferred to other proteins to be transported to tissue cells and then carried throughout the body. One of the organs that receive retinol is a fish pituitary that functions to stimulate the pituitary gland to produce fish color [14]. The enhancement seen in treatment A (control) is allegedly caused by the carotene content in commercial feed. [15] stated that in the commercial feed used as test feed, another source of carotene, $B$-carotene, is available from the fish meal.

To identify which treatment experiences the highest increase in color enhancement score, one-way Kruskal-Wallis statistical test was used to assess the color score difference between the color scale at the start of observation and the end of observation in each treatment (Table 3).

Kruskal-Wallis test results of botia fish body and caudal fin color (Table 1) show that the combination of Tubifex and carrot meals increased the color value in each treatment, especially in treatment $\mathrm{D}$ and $\mathrm{E}$ resulted significantly different from treatment $\mathrm{A}$ (control) but were not significantly different from treatments B, C, and F. The fish color enhancement is influenced by the absorption of pigment dose, chemical structure of the type of pigment given, and the chromatophore cells contained in the fish [16].

The Kruskal-Wallis test result on the color value in treatment B did not present an optimum increase, leading to a non-significant difference compared to treatment A (control) in body color but a significant difference in the caudal fin. This might be due to the amount 
of carrot meal in treatment $\mathrm{B}$, which was smaller than the amount in other treatments. Treatment $\mathrm{C}$ resulted in a lower color value when compared to treatment $\mathrm{B}$, with no significant difference in both body and caudal fin color values from treatment $\mathrm{A}$ (control). This was thought to be caused by the internal factor of the fish that experienced stress during the final observation. When fish experiences stress, the epinerfin hormone (adrenaline) will be activated and the pigment in the chromatophore cells will gather in the middle part of the cell, causing the fish to lose color [17]. [18] stated that acetylcholine, which is a chemical released by nerve cells to the muscles, causes the melanin to spread and fish body color becomes darker.

Table 3. Color Value in Botia Body and Fish caudal fin for 40 days after being fed with diet Diet Containing Different Level Tubifex and Carrot Meal

\begin{tabular}{|c|c|c|}
\hline \multirow{2}{*}{ Treatment } & \multicolumn{2}{|c|}{ Average Score on the 40th day } \\
\cline { 2 - 3 } & Body & caudal fin \\
\hline A & $95.622^{\mathrm{a}}$ & $97.033^{\mathrm{a}}$ \\
\hline B & $139.78^{\mathrm{abc}}$ & $142.9^{\mathrm{b}}$ \\
\hline C & $134.7^{\mathrm{abc}}$ & $140.967^{\mathrm{ab}}$ \\
\hline D & $165.49^{\mathrm{c}}$ & $159.867^{\mathrm{b}}$ \\
\hline E & $143.74^{\mathrm{bc}}$ & $143.733^{\mathrm{b}}$ \\
\hline F & $133.67^{\mathrm{ab}}$ & $128.5^{\mathrm{ab}}$ \\
\hline
\end{tabular}

Notes: Numbers followed by the same letters are not significantly different vertically based on the $\mathrm{Z}$ test, with a confidence level of $95 \%$.

The color produced in treatment D was a bright orange color with the code of TCF 0605 on the body and clear orange color on the caudal fin with the code of TCF 0805. According to [4], one of the advantages of natural feed for fish is that the cell content is dense and the cell wall is thin, making it easier to be absorbed by the fish. The color value in treatment $\mathrm{E}$ was the second-highest after treatment D. It is suspected that supplementation in the feed has reached the optimum limit, which is apparent from the lower color enhancement score increase when compared to treatment D. According to [19], in order to obtain the best color, the color pigment source dose should be accurate, not more or less. It has to be in an optimum dose because when carotene is added to the feed in a higher than optimum dose, it will not lead to a better color and may even reduce the color quality. The combination feed-in treatment $\mathrm{F}$ produced a small color value when compared to other treatments, except for treatment A (control). It was suspected that the color-related supplementation given to the fish has exceeded the optimum limit. [20] stated that when a color-related supplementation exceeds the optimum limit of the fish, color-related supplement will be excreted into feces.

The improvement of color quality in this study ranged from 159,867-165.49. This value is higher than the increase in the level of color in koi fish by using pumpkin as a source of pigment that is equal to 50,525[21]. The use of different carotenoid sources from butterfly pea leaf meal on koi fish (Cyprinus carpio) also gave a lower value compared to the results in this study. The addition of $6 \%$ pea leaf meal flour in feed formulation is the most effective dose to improve the quality of the color of caudal fin with the highest color intensity value of 82.16 [22]. The improvement of color quality in ornamental fish is influenced by several factors, including carotene content in pigment sources, fish body fat content and the ability of fish to absorb carotenoids [23] 


\subsection{Survival Rate}

All treatments resulted in $100 \%$ survival rate. The good survival rate in this study was achieved through the good feed diet, fish density management, and culture media environment. The feed with a combination of Tubifex natural food and carrot meal provided required nutrient content for the fish to support its survival. The protein content in the feed can be used to form antibodies that protect against any foreign substances that enter the fish [24]. Food that contains a high level of fat will produce far greater energy. However, omnivorous fish uses fat less efficiently when compared to the carnivorous species [25]. The fat in Tubifex natural feed is converted into provitamin A, which is an important micronutrient to increase fish growth, development, immune system, and biomass [26]

The density of the test fish is regulated to produce the optimum survival rate [27]. The fish density in this study is 5 fish per aquarium. Botia fish is a species of fish that likes to live in a group of $4-6$ or more [2]. The cleanliness of the culture media also plays a role in providing a good environment for the test fish. [28] stated that materials that are not useful and even detrimental to fish will be sedimented at the bottom of the culture container that dilution is needed to dispose of these materials. The survival rate of botia fish seeds reaches more than $50 \%$ [29]. This result is in line with the study of [30], in which no effect of the carotenoid dietary supplement was found in the survival of Hyphessobrycon callistus.

\subsection{Water Quality}

Water quality parameters observed including temperature, $\mathrm{DO}, \mathrm{pH}$, and ammonia level. A water sample from each aquarium was tested in the Water Quality Laboratory of the Ornamental Fish Seed Research Center, Depok. Water quality testing in this study was conducted at the beginning and the end of the study (Table 4).

Measurement of water quality at the beginning and the end of the study presented an average value of the initial temperature of $28^{\circ} \mathrm{C}$ and the final temperature of $26.5^{\circ} \mathrm{C}$. In botia natural habitat, the natural temperature ranges from $24^{\circ} \mathrm{C}$ to $30^{\circ} \mathrm{C}$ [29]. The average DO (dissolved oxygen) levels at the beginning and the end of the study were 5.78 and 5.19, respectively. [31] suggested that the optimum oxygen demand is around 5 to $7 \mathrm{mg} / \mathrm{L}$. The average acidity $(\mathrm{pH})$ was 6.53 at the beginning of the study and 6.17 at the end of the study. For botia fish, the acidity of water in their natural habitat reaches 5.0 to 7.0 [29]. At the end of the study, the average ammonia levels were 0.03. According to Amin [32], the maximum limit of ammonia content in fish culture media is $1 \mathrm{mg} / \mathrm{L}$.

Table 4. Water Quality Parameters During Research

\begin{tabular}{|c|c|c|c|c|}
\hline \multicolumn{5}{|c|}{ Observed Parameters } \\
\hline Treatment & $\begin{array}{c}\text { Temperature } \\
\left({ }^{\circ} \mathrm{C}\right)\end{array}$ & DO $(\mathrm{mg} / \mathrm{L})$ & $\mathrm{pH}(-)$ & $\begin{array}{c}\text { Ammonia Level } \\
(\mathrm{mg} / \mathrm{L})\end{array}$ \\
\hline $\mathrm{A}$ & $28.0-26.5$ & $5.78-5.11$ & $6.53-6.08$ & $(\mathrm{ND})-0.02$ \\
\hline $\mathrm{B}$ & $28.0-26.7$ & $5.78-5.22$ & $6.53-6.13$ & $(\mathrm{ND})-0.04$ \\
\hline $\mathrm{C}$ & $28.0-26.5$ & $5.78-5.17$ & $6.53-6.27$ & $(\mathrm{ND})-0.03$ \\
\hline $\mathrm{D}$ & $28.0-26.5$ & $5.78-5.42$ & $6.53-6.10$ & $(\mathrm{ND})-0.03$ \\
\hline $\mathrm{E}$ & $28.0-26.7$ & $5.78-5.06$ & $6.53-6.18$ & $(\mathrm{ND})-0.04$ \\
\hline $\mathrm{F}$ & $28.0-26.6$ & $5.78-5.19$ & $6.53-6.28$ & $(\mathrm{ND})-0.03$ \\
\hline Methods & Instruments & Instruments & $\begin{array}{c}\mathrm{SNI} \\
06.6989 .11 .2004\end{array}$ & $\begin{array}{c}\text { SNI } \\
06.6989 .30 .2005\end{array}$ \\
\hline Optimal & $24-30^{(1)}$ & $5-7^{(2)}$ & $5,0-7,0^{(1)}$ & $0-1,0^{(3)}$ \\
\hline
\end{tabular}

Notes : ND = Not Detected, [29] $]^{1},[31]^{2},[32]^{3}$. 


\section{Conclusions}

The diet of 50\% Tubifex natural feed and 5\% carrot meal in 45\% commercial feed produces the best color enhancement in botia with an average body color value of 5.04 with 6 as the best score and Toca Color Finder code of 0605. Fish caudal fin color also undergoes an increase with an average color value of 3.93 with 5 as the best score and Toca Color Finder code of 0805 . The combination of Tubifex natural feed and carrot meal results in a $100 \%$ fish survival rate.

\section{References}

1. E. F. H. Putra, S. P. Rahardjo, A. Permana. Botia Fish, JAFH, 6 (2017)

2. H. Dahruddin, Maskotnya Ekspor Ikan Hias Asli Indonesia, FI, 10 (2011)

3. R. R. Jannah, E. I. Raharjo, Rachimi, Pengaruh Tepung Bunga Marigold Terhadap Kualitas Warna Ikan Botia, FFMS (to be published)

4. S. A. Djarijah, Pakan Alami Ikan (Kanisius, Yogyakarta, 1995)

5. Khairuman, K.Amri, Peluang Usaha dan Teknik Budidaya Lele Sangkuriang (PT Gramedia Pustaka Utama, Jakarta, 2008)

6. T. A. D. Utami, Y. Aida, S. Pranata, Kualitas Warna Ikan Koi, Doctoral Dissertation, UAJY (2014)

7. N. Andrawulan, RH. F. Faradillah, Pewarnaan Alami Untuk Pangan (Seafast Center, IPB, 2012)

8. R.M. Karo-karo, S. Usman, I. Irwanmay, Pengaruh Konsentrasi Tepung Wortel (Daucus carota) pada Pakan terhadap Peningkatan Warna Ikan Maskoki (Carassius auratus), Aquacostamarine, 10 (2015)

9. M. I. Effendie, Biologi Perikanan (YPN, Yogyakarta, 1997)

10. S. Subekti, M. Prawesti, M. Arief, Pakan Alami Ikan Sidat, JK, 4 (2011)

11. T.A.D. Utami, Y. Aida, S.Pranata, Variasi Kombinasi Tepung Labu Kuning (Cucurbita moschata D) dan Tepung Azolla (Azolla pinnata R.br.) pada Kecerahan Warna Ikan Koi (Cyprinus Caprio L.), (Doctoral Dissertation, UAJY, 2014)

12. T. Latschar, Carotenoids, their Nature and Significants in Animal Feeds (Hoffmann-La Roche, Basel, 1990)

13. H. Handjani, W. Widodo, Nutrisi Ikan (UMM Press, Malang, 2010)

14. Subamia, I Wayan, M. Nina, L. M. Karunia, Kualitas Warna Ikan Rainbow Merah, JII, $10(2010)$

15. E. Widinata, K. Muslih, A. Kurniawan, Bunga Marigold dan Udang Rebon Terhadap Kecerahan Warna Ikan Koi, Akuatik, JSP, 10 (2016)

16. Sukarman, Chumaidi, Bunga Tai Kotok Sumber Karotenoid pada Ikan Hias, JBRBIH, 803-807 (2010)

17. A. H. Pardosi, S. Usman, I. Lesmana, Tepung Wortel Terhadap Kualitas Warna Ikan Koi, Aquacoastmarine, 11 (2015)

18. S. Indarti, M. Muhaemin, S. Hudaidah, Tingkat Kecerahan Ikan Komet, JRTBP, 1 (2012)

19. E. Sitorus, L. I. Momuat, D. G. Katja, Aktivitas Antioksidan Tumbuhan Suruhan, JIS, 13 (2013) 
20. D. M. Deming, Erdman, J. W. Jr, Mammalian carotenoid absorption and metabolism (Pure and Applied Chemistry, 1999)

21. A.Yustiati, A. Yuni, H. Titin, R. Budi, Y, Andriani, The Implementation of Natural Pigments of Pumpkin Meal to enhance the Color Quality of Koi Fish (Cyprinus carpio), RJCE, Special Issue (2018)

22. R.O. Julia, Y. Andriani, P. Lintang, S. Yuliadi, Iskandar, The Effect of Addition of Butterfly Pea Leaf Meal (Clitoria ternatea) in Feed on the Quality of Color of Swordcaudal fin Fish Head (Xiphophorus helleri). WNOFNS, 26 (2019)

23. M. Yanar, Z. Erçen, A. ö. Hunt, and H. M. Büyükçapar, The Use of Alfalfa as a Natural Carotenoid Source in Diets of Goldfish, Carassius auratus, Aquaculture, 284 (2008) [23]

24. Mudjiman, Makanan Ikan, (Penebar Swadaya, Jakarta, 2008)

25. Y. Andriani, R. Rostika, K. Haetami, U. Subhan, Nutrisi Ikan (Unpad Press, Bandung, 2016)

26. U. D. Enyi, J. Nwahiri, Growth, and vitamin A enhancement effects of provitamin a $\beta$ carotenoid cassava, IJISABF, Nigeria, 3 (2017)

27. R. P. Tarigan, Y. Djayus, I. Lesmana, Laju Pertumbuhan Benih Ikan Botia, JA, 3 (2014)

28. M. Sari, M. Hatta, A. Permana, Pemeliharaan Larva Ikan Botia, AA, 1 (2014)

29. Ministry of Fishery and Maritime Affairs Regulation, Arwana and Botia Fish Fry, PERMEN-KP, Indonesia, 21 (2014)

30. Y.J. Wang, Y.H. Chien, C.H. Pan, Effects of Dietary Supplementation of Carotenoids on Survival, Growth, Pigmentation, and Antioxidant Capacity of Characins, Hyphessobrycon callistus, JA, 261 (2006)

31. M. G. H. Kordi, A. B. Tancung, Pengelolaan Kualitas Air, (Rineka Cipta, Jakarta, 2010)

32. Amin, Rosidah, Lili, Peningkatan Warna Udang Red Cherry, JPK, 3 (2012)

33. J. Ezhil, C. Jeyanthi, M.Narayanan, Marigold as a Carotenoid Source on Pigmentation and Growth of Red Swordcaudal fin, Xiphophorus helleri, TJFAS, 8 (2008)

34. C.T. Kalinowski, L.E. Robaina, H. Fernandez-Palacios, D. Schuchardt, M.S. Izquierdo, Effect of Different Carotenoid Sources and Their Dietary Levels on Red Porgy (Pagrus pagrus) Growth and Skin Colour, Aquaculture, 244 (2005) 